\title{
Kejadian Gangguan Depresi pada Penderita HIV/AIDS yang Mengunjungi Poli VCT RSUP Dr. M. Djamil Padang Periode Januari - September 2013
}

\author{
Yaslinda Yaunin ${ }^{1}$, Rudi Afriant ${ }^{2}$, Nurul Maulidya Hidayat $^{3}$
}

\begin{abstract}
Abstrak
Infeksi HIV/AIDS sangat erat hubungannya dengan gangguan depresi. Penyebabnya bisa dikarenakan faktor psikologisnya ataupun efek dari agen HIV yang sudah menginfeksi sistem saraf pusat. Salah satu metode pencegahan gangguan depresi yang dapat diberikan adalah pemanfaatan poli VCT (Voluntary Counseling and Testing) dengan baik. Penelitian ini bertujuan untuk mengetahui gambaran kejadian gangguan depresi pada penderita HIV/AIDS yang mengunjungi poli VCT RSUP DR. M. Djamil Padang periode Januari-September 2013. Metode penelitian adalah deskriptif dengan jumlah sampel sebanyak 43 orang. Data dikumpulkan melalui pengisian kuesioner Hamilton Depression Rating Scale dan hasil yang didapat disajikan dalam bentuk tabel distribusi frekuensi. Hasil penelitian ini menunjukkan bahwa penderita HIV/AIDS yang mengunjungi poli VCT RSUP DR. M. Djamil Padang periode Januari - September 2013 didapatkan tidak mengalami depresi sebanyak 44,2\% sedangkan untuk depresi sebanyak $55,8 \%$ dengan pembagian depresi ringan hanya $25,6 \%$, depresi sedang $11,6 \%$, depresi berat $4,7 \%$, dan depresi sangat berat 14\%. Depresi terbanyak ditemukan pada usia $20-39$ tahun $(83,3 \%)$.
\end{abstract}

Kata kunci: penderita HIV/AIDS, gangguan depresi, poli VCT

\begin{abstract}
HIVIAIDS infection is associated with depression disorders. Etiology may be cause of psychososcial factor or the effect of HIV agent that infected central nervous system. In order to prevent depression disorders is by the utilization VCT (Voluntary Counseling and Testing) Clinic This study aims to describe the incident rate of depressive disorder among people living with HIVIAIDS visited VCT clinic at RSUP DR. M. Djamil Padang in January-September 2013. The research method was descriptive and made up by 43 HIV/AIDS-infected patients. Data were collected through filling Hamilton Depression Rating Scale and the results are presented in the form of a frequency distribution table. The results obtained that people living with HIVIAIDS visited VCT clinic at RSUP DR. M. Djamil Padang in January-September 2013 are not experiencing depression, representing 44,2\% and 55,8\% for depressive disorder which is mild depression only obtained $25,6 \%$, moderate depression $11,6 \%$, severe depression $4,7 \%$, and very severe depression 14\%. Depression disorder more found in the age : 20 - 39 years (83,3\%).
\end{abstract}

Keywords: HIVIAIDS patient, depression disorder, VCT clinic

Affiliasi penulis : 1.Bagian Psikiatri FK Unand, 2 Bagian Penyakit Dalam FK Unand, 3.Fakultas Kedokteran Universitas Andalas

Korespondensi : Yaslinda Yaunin, email: linda_yns@yahoo.co.id, Telp: 0811667236

\section{PENDAHULUAN}

Seseorang yang mengalami depresi ditandai dengan hilangnya rasa senang atau ketertarikan terhadap hal-hal yang biasanya disukai. Kira-kira dua pertiga pasien depresi mengalami fikiran akan bunuh diri dan sekitar 10 - 15\% melakukan bunuh diri. Depresi bisa disebabkan oleh faktor biologik seperti gangguan keseimbangan neurotransmitter (norepinefrin, serotonin, dopamine, gamma amino butyric acid), gangguan regulasi hormon, faktor genetik dan yang tidak kalah pentingnya adalah faktor psikososial (stress kehidupan, kepribadian). ${ }^{1}$ Infeksi HIV/AIDS sangat erat hubungannya dengan gangguan depresi. Penyebabnya bisa dikarenakan faktor psikologisnya ataupun efek dari agen HIV yang sudah menginfeksi sistem saraf pusat. Perjalanan penyakit HIV/AIDS yang progresif, penyebarannya yang luas dan cepat serta adanya stigma dan diskriminasi pada pasien HIV/AIDS dapat menimbulkan stres pada penderitanya. Bila gangguan psikologis ini tidak ditatalaksana dengan baik, maka besar kemungkinan seseorang yang mengalami
HIV/AIDS mengalami depresi. ${ }^{2}$ Jumlah orang yang terkena HIV-AIDS didunia sampai akhir 2010 mencapai 34 juta orang dimana dua pertiganya terdapat di Afrika Selatan kawasan Selatan Sahara. Di kawasan itu kasus infeksi baru mencapai tujuh puluh persen, di Afrika Selatan 5,6 juta orang terinfeksi HIV, Asia Pasifik menempati tempat kedua dengan jumlah penderita HIV-AIDS mencapai lima juta orang. Eropa Tengah dan Barat jumlah kasus infeksi baru HIV/AIDS sekitar 840 ribu, di Jerman secara kumulasi ada 73 ribu orang. ${ }^{3}$ Sedangkan di Indonesia terdapat 5.442 kasus HIV yang dilaporkan oleh Kemenkes dari bulan Oktober sampai Desember 2011. Menurut Dinas Kesehatan Sumbar pada tahun 2008 ditemukan 111 kasus HIV-AIDS dan terjadi peningkatan jumlah kasus pada tahun 2009 sebanyak 154 kasus. Namun pada tahun 2010, kasus HIV sempat mengalami penurunan kasus menjadi 138. Dan pada tahun 2012 kasus HIV meningkat lagi menjadi 189 orang yang terkena HIV. ${ }^{4}$ Apabila dilihat berdasarkan jenis kelamin, kasus AIDS dilaporkan banyak ditemukan pada laki-laki yaitu $74,5 \%$, sedangkan perempuan $25 \%$. Laporan Kementerian Kesehatan $\mathrm{RI}$ tentang perkembangan HIV/AIDS di Indonesia pada Triwulan IV (dari bulan Oktober sampai dengan Desember tahun 2011) jumlah kasus HIV yang dilaporkan sebanyak 5.442 kasus. ${ }^{4} \quad$ Penelitian Hawari pada 350 orang yang 
menjalani terapi detoksifikasi NAZA hanya 57 orang bersedia dilakukan tes HIV/AIDS (16,29\%). Dari 57 orang tersebut ternyata 19 orang positif HIV/AIDS $(33,33 \%){ }^{5}$

.Penelitian yang dilakukan di India menunjukan bahwa pasien HIV/AIDS dengan status perkawinan bercerai memiliki angka depresi yang cukup tinggi dibandingkan yang belum menikah dan sudah menikah. Hal ini dikarenakan kurangnya dukungan dari keluarga dekat. ${ }^{6}$ Penderita HIV/AIDS yang mengalami depresi cendrung akan melakukan bunuh diri terutama pada saat awal mengetahui terinfeksi HIV sebagai suatu respon impulsive dari gejolak emosinya, juga resiko bunuh diri akan meningkat pada saat penyakit berlanjut yang menyebabkan kemampuan fisik dan mental makin menurun.

Dukungan sosial merupakan salah satu penangan yang cukup efektif dalam penanganan depresi pada pasien HIV/AIDS. Semakin besar dukungan sosial yang diberikan, maka semakin kecil angka terjadinya depresi. Dukungan sosial ini bisa dari keluarga dekat, teman-teman, lingkungan sekitar bahkan pemerintah. Salah satu layanan pemerintah dalam penanganan gangguan kejiwaan ini adalah Poli VCT (Voluntary Counseling and Testing) atau KTS (Konseling dan Tes Sukarela). Dalam pelayanan ini dilakukan beberapa hal seperti konseling pra-testing, testing HIV, dan konseling post-testing secara sukarela atau kesadaran dari individu sendiri. Konseling pra-testing memberikan pengatahuan tentang HIV dan manfaat testing HIV, pengambilan keputusan untuk testing, dan perencanaan atas issue HIV yang akan dihadapi. Konseling post-testing membantu seseorang untuk mengerti dan menerima status $(\mathrm{HIV}+)$ dan merujuk pada pelayanan dukungan. Konseling ini dilakukan oleh konselor yang merupakan tenaga kesehatan terlatih dengan klien atau individu yang merasa memiliki risiko tinggi HIV/AIDS serta dilakukan secara rahasia dan sukarela. ${ }^{7}$ Pengobatan Spiritual juga bisa meringankan beban penderita HIV/AIDS. Ironson pada tahun 2000 melakukan penelitian dan menemukan bahwa terapi agama (psikoreligius) mempunyai peran penting dalam memperpanjang usia seorang penderita HIV/AIDS. ${ }^{5}$

Penelitian ini bertujuan mengetahui gambaran angka kejadian gangguan depresi pada pasien HIV/AIDS yang mengunjungi poli VCT RSUP DR. M. Djamil Padang periode Januari - September 2013.

\section{METODE}

Jenis penelitian ini adalah penelitian deskriptif dengan pendekatan metode cross sectional.

Penelitian dilakukan di bagian Poli VCT RSUP DR. M. Djamil Padang pada bulan November 2013-Desember 2013. Populasi pada penelitian ini adalah pasien HIV/AIDS yang mengunjungi Poli VCT RSUP DR. M. Djamil Padang bulan Januari sampai September 2013. Kriteria Inklusi adalah sebagai berikut: Pasien HIV/AIDS yang mengunjungi Poli VCT RSUP DR. M. Djamil Padang, Tidak memiliki riwayat gangguan depresi sebelumnya, Pasien yang telah menyetujui penelitian ini.Sedangkan Kriteria Eksklusi: Pasien yang pernah mengalami gangguan mood (afektif) lain sebelumnya selain gangguan mood (afektif) episode depresi, Pasien yang menolak untuk dilakukan pemeriksaan. Teknik Pengambilan Sampel: Pasien HIV/AIDS yang mengunjungi Poli VCT akan diajukan beberapa pertanyaan data demografi dan kuesioner Hamilton Depression Rating Scale.

\section{HASIL PENELITIAN}

Hasil penelitian ini menemukan bahwa jumlah kunjungan pasien HIV/AIDS pada periode JanuariSeptember 2013 di poli VCT RSUP DR. M. Djamil adalah 49 orang dan 19 orang tidak mengalami depresi $(44,2 \%)$ serta 24 orang depresi (55,8\%). Dari yang mengalami depresi ada 19 orang laki-laki $(79,2 \%)$ dan 5 orang perempuan $(20,85)$.

Gambaran tingkat depresi pada 24 orang yang mengalami depresi dapat dilihat pada tabel 1.

Tabel 1. Distribusi TingkatKeparahan Depresi Pasien yang Mengunjungi Poli VCT RSUP DR. M. Djamil Periode Januari-September 2013.

\begin{tabular}{lll}
\hline Tingkat Depresi & F & $\%$ \\
\hline & & \\
Depresi Ringan & 11 & 45,8 \\
Depresi Sedang & 5 & 20,8 \\
Depresi Berat & 2 & 8,4 \\
Depresi Sangat Berat & 6 & 25 \\
\hline Total & 24 & 100 \\
\hline
\end{tabular}

Berdasarkan tabel 1. didapatkan pasien HIV/AIDS yang mengunjungi poli VCT RSUP DR. M. Djamil Padang periode Januari - September 2013 terbanyak mengalami depresi ringan, $45,8 \%$ paling sedikit depresi berat (25\%)

Tabel 2. Distribusi Frekuensi Gangguan Depresi Berdasarkan Usia Pasien HIV/AIDS yang Mengunjungi Poli VCT RSUP DR. M. Djamil Periode JanuariSeptember 2013

\begin{tabular}{lll}
\hline Usia & \multicolumn{2}{l}{ Depresi } \\
\cline { 2 - 3 } & F & $\%$ \\
\hline$<20$ tahun & 1 & 4,2 \\
$20-29$ tahun & 6 & 25 \\
30-39 tahun & 14 & 58,3 \\
$\geq 40$ tahun & 3 & 12,5 \\
\hline Total & 24 & 100 \\
\hline
\end{tabular}

Berdasarkan tabel 2. didapatkan umur pasien HIV/AIDS yang mengalami gangguan depresi terbanyak adalah pada usia 30 - 39 tahun yaitu sebanyak $58,3 \%$. Sedangkan untuk persentase yang terendah ditemukan pada usia <20 tahun yaitu sebanyak $4,2 \%$.

Hasil penelitian mengenai distribusi frekuensi gangguan depresi subjek penelitian berdasarkan status perkawinan pasien HIV/AIDS yang mengunjungi poli VCT RSUP DR. M. Djamil periode JanuariSeptember 2013 dapat dilihat pada tabel di bawah ini. 
Tabel 3. Distribusi Frekuensi Gangguan Depresi Pasien HIV/AIDS yang Mengunjungi Poli VCT RSUP DR. M. Djamil Periode Januari - September 2013 Berdasarkan Status Perkawinan

\begin{tabular}{lll}
\hline Status Perkawinan & \multicolumn{2}{l}{ Depresi } \\
\cline { 2 - 3 } & F & $\%$ \\
\hline Belum Menikah & 11 & 45,8 \\
Menikah & 12 & 50 \\
Bercerai & 1 & 4,2 \\
\hline Total & 24 & 100 \\
\hline
\end{tabular}

Berdasarkan tabel 3. didapatkan status perkawinan pasien HIV/AIDS yang mengunjungi poli VCT RSUP DR. M. Djamil periode Januari September 2013 terbanyak adalah pada pasien yang menikah yaitu sebanyak $50 \%$, sedangkan frekuens terendah pada pasien yang bercerai yaitu sebanyak $4,2 \%$.

Kalau dilihat dari segi faktor resiko terjadinya infeksi pada psien HIV/AIDS yang mengunjungi poli VCT RSUP DR. M. Djamil periode Januari September 2013 dapat dilihat pada tabel 4 di bawah ini.

Tabel 4. Distribusi Frekuensi Gangguan Depresi Berdasarkan Faktor Risiko.

Pasien HIV/AIDS yang Mengunjungi Poli VCT RSUP DR. M. Djamil Periode Januari - September 2013

\begin{tabular}{lll}
\hline Faktor Risiko & \multicolumn{2}{l}{ Depresi } \\
\cline { 2 - 3 } & F & $\%$ \\
& & \\
\hline Pengguna Narkoba Jarum Suntik & 4 & 16,7 \\
Seks Bebas & 15 & 62,5 \\
Istri Pasien HIV/AIDS & 2 & 8,3 \\
Transfusi Darah & 2 & 8,3 \\
Lain-lain & 1 & 4,2 \\
\hline Total & 24 & 100 \\
\hline
\end{tabular}

Berdasarkan tabel 4. didapatkan faktor risiko pasien HIV/AIDS yang mengalami depresi terbanyak adalah karena seks bebas $62,5 \%$ dan yang terendah adalah faktor risiko lain-lain sebanyak $4,2 \%$.

\section{PEMBAHASAN}

Dari hasil penelitian derajat keparahan depresi pada penelitian ini didapatkan ialah mengalami gangguan depresi sebanyak 55,8\% dengan pembagian depresi ringan $25,6 \%$, depresi sedang $11,6 \%$, depresi berat $4,7 \%$, dan depresi sangat berat $14 \%$ sedangkan untuk bukan depresi sebanyak 44,2\%. Unnikrishnan,dkk (2012) menyebutkan pasien HIV/AIDS yang mengalami depresi sebanyak $20-39 \%$ (5) Kurang maksimalnya pemanfaatan pelayanan poli VCT dan dukungan dari masyarakat dapat menyebabkan tingginya angka depresi. Ada sejumlah faktor psikososial yang diprediksi sebagai penyebab gangguan mental pada seseorang yang pada umumnya berhubungan dengan kehilangan. Faktor psikososial tersebut adalah hilangnya peranan sosial, hilangnya otonomi, kematian teman atau sanak saudara, penurunan kesehatan, peningkatan isolasi diri, keterbatasan finansial, dan penurunan fungsi kognitif. ${ }^{1}$
Dari hasil penelitian yang dilakukan berdasarkan usia, pasien HIV/AIDS yang menderita depresi pada usia $<20$ tahun sebanyak 4,2\% dan pada usia 20-29 tahun sebanyak 25\%. Untuk usia 30-39 tahun ditemukan $58,3 \%$ mengalami depresi dan pada usia $\geq 40$ tahun sebanyak $12, \%$. Prevalensi gangguan depresi pada populasi dunia terbanyak pada usia produktif yaitu 20 - 50 tahun. Alasan perbedaan telah diteliti melibatkan perbedaan hormonal, perbedaan stressor psikososial dalam rentang umur tersebut. ${ }^{1}$ Perbedaan pada penelitian ini bisa disebabkan karena pasien HIV/AIDS rawat jalan pada saat penelitian yang banyak mengunjungi poli VCT adalah kelompok usia 30-39 tahun.

Hasil penelitian tentang jenis kelamin pada penelitian ini didapatkan persentase gangguan depresi pasien HIV/AIDS laki-laki sebanyak $79,2 \%$ dan perempuan yaitu sebanyak $20,8 \%$, namun secara umum kasus depresi prevalensinya lebih tinggi pada wanita. Menurut Kaplan dan Shadock (2007) yaitu $20 \%$ pada wanita dan $12 \%$ pada laki-laki. ${ }^{1}$ Penelitian Unnikrishnan, dkk (2012) didapatkan prevalensi depresi $5-12 \%$ pada pria dan $10-25 \%$ pada wanita. ${ }^{6}$ Penelitian ini sesuai dengan penemuan Kementrian Kesehatan RI bahwa penderita HIV/AIDS lebih banyak pada laki-laki. $^{7}$

Prevalensi penelitian gangguan depresi pada status perkawinan terbanyak didapatkan pada pasien yang belum menikah yaitu sebanyak 45,8\% sedangkan untuk yang menikah sebanyak $50 \%$ dan yang bercerai sebanyak $4,2 \%$. Unnikrishnan, et al. (2012) menyebutkan bahwa gangguan depresi yang terbanyak adalah pada yang menikah (44,6\%). Persamaan ini didapatkan karena pada pasien HIV/AIDS yang sudah menikah pada umumnya memiliki banyak kendala dalam kehidupannya. Dimulai dari permasalahan rumah tangga, permasalahan ekonomi keluarga, ditambah lagi dengan kurangnya dukungan dari keluarga dekat dan linkungan. Hal ini dapat menyebabkan meningkatnya stress mental pada pasien HIV/AIDS yang apabila tidak ditangani dengan baik, dapat menjadi gangguan depresi. ${ }^{6}$

Sebanyak $16,7 \%$ pada tahun 2013 gangguan depresi pasien HIV/AIDS memiliki faktor risiko penularan melalui pengunaan narkoba jarum suntik. Untuk faktor risiko seks bebas didapatkan 62,5\% sedangkan isteri pasien HIV/AIDS memiliki angka $8,3 \%$, transfusi darah $8,3 \%$, dan untuk lain-lain $4,2 \%$. Penelitian yang dilakukan oleh Unnikrishnan, et al. (2012) menyebutkan bahwa depresi lebih sering terjadi pada faktor risiko penularan melalui narkoba jarum suntik. ${ }^{6}$ Pelaku seks bebas terutama perempuan juga terjadi depresi dikarenakan perempuan memiliki kehangatan, emosionalitas, sikap hati-hati, sensitivitas, dan konformitas lebih tinggi daripada lakilaki, sedangkan laki-laki lebih tinggi dalam stabilitas emosi, dominasi dan impulsivitas dari pada perempuan. $^{3}$

\section{KESIMPULAN}

Berdasarkan hasil penelitian ini didapatkan 49 orang penderita HIV/AIDS yang mengunjungi poli VCT RSUP DR. M Djamil Padang pada periode Januari - September 2013 yang mengalami depresi sebanyak 24 orang (55,8\%). Usia terbanyak mengalami depresi adalah pada usia 20 - 39 tahun $(83,3 \%)$. Berdasarkan tingkat depresinya didapatkan: 
depresi ringan $(45,8 \%)$, depresi sedang (20,8\%), depresi berat $(8,4 \%)$ dan depresi sangat berat $(25 \%)$.

\section{DAFTAR PUSTAKA.}

1. Kaplan \& Sadock's, Synopsis of Psychiatry Behavioral Science/ Clinical Psychiatry, Xth Edition, Lippincott Wilkins \& Wilkins, Philadelphia, 2007, pp $527-78$.

2. Wahyu S, Taufik, et al., Konsep Diri dan Masalah yang Dialami Orang Terinfeksi HIV/AIDS, Konselor, 2012, Vol.1, hal 1-12.

3. United Nations Programme on HIV/AIDS (UNAIDS), Getting To Zero. Diambil pada 29 September 2013

dari
4. Komisi Penanggulangan AIDS (KPA), Situasi HIV \& AIDS di Indonesia, 2009.

5. Hawari,D. Konsep Agama (Islam) Menanggulangi NAZA, PT. Dana Bhakti Prima Yasa, Yogyakarta, 2002.

6. Unnikrishnan B, Jagganath $\mathrm{V}$, Ramapuram JT, Achappa B, Madi D, 2012. Study of Depression and Its Associated Factors among Women Living with HIV/AIDS in Coastal South India. Dalam (R. L. D. Machado, M. Patel, dab J. Poudrier ed) ISRN AIDS, 2012, Vol.12.

7. Departemen Kesehatan RI, Modul Pelatihan Konseling dan Tes Sukarelawan HIV (Voluntary Counselling and Testing $=$ VCT $)$, 2004. 